Yıl: 23 Cilt: 23 Sayı: 2 Aralık 2021 s. 178-199 Makale Türü: Araştırma

Makalenin Geliş Tarihi: 17.05.2021 Makalenin Kabul Tarihi: 23.08.2021

\title{
Olağanüstü Hal Çerçevesinde Hukuk ve Siyaset İlişkisi: ABD’nin Teröre Karşı Savaşı ve İstisna Halinin Mekânsal Temsilleri Olarak Guantanamo ve Ebu Gureyb
}

\author{
Zeynep Arı̈̈z*, Muhammed Kürşad Özekin ${ }^{* *}$
}

\begin{abstract}
Öz: Hukuk ve siyaset ilişkisi, siyasetin, hukuk üzerinde adaleti ve tarafsızlığı bozan etkileri bakımından tartışmalı olmayı sürdürmektedir. Olağanüstü hal kavramı, bu tartışmanın belirginleştiği bir ara bölgedir. Çalışmada, Carl Schmitt, Walter Benjamin ve Giorgio Agamben gibi düşünürlerin olağanüstü hal kuramlarına atıf yapılarak, hukuk ile egemen arasındaki ilişkiyi ve siyasal olanla yasal olan arasındaki çatışmayı tartışmak amaçlanmıştır. Bu bağlamda, ABD’nin 11 Eylül saldırılarının ardından teröre karşı açtığı savaş ve izlediği tek taraflı dış politika ile olağanüstü hal arasındaki ilişkiye odaklanılacaktır. Saldırıların ardından ABD dış politikası, pro-aktif ve ofansif güvenlik stratejilerinin hakim olduğu yeni bir döneme girmiştir. ABD, Güvenlik Konseyi’nin açık bir yetkilendirmesi olmaksızın Irak ve Afganistan'a askeri müdahalede bulunmuş ve ele geçirilen teröristlerin tutukluluk ve yargılanma süreçleri konusunda uluslararası hukuku askıya alan bir dizi uygulama, yasalar ve Başkanlık Emirleri aracılığıyla hayata geçirilmiştir. Çalışmada Guantanamo ve Ebu Gureyb cezaevleri, ABD’nin tek taraflı dış politikası bağlamında tartışılarak, hukukun, egemenin kararları lehine araçsallaştırıldığı, istisna halinin mekânsal temsilleri olarak değerlendirilecektir.
\end{abstract}

Anahtar Kelimeler: ABD Dış Politikası, 11 Eylül Saldırıları, Terörizme Karşı Küresel Savaş, Olağanüstü Hal, Guantanamo, Ebu Gureyb.

\footnotetext{
* Dr. Öğretim Üyesi, Bandırma Onyedi Eylül Üniversitesi, İ.İ.B.F, Uluslararası İlişkiler Bölümü, zarioz@bandirma.edu.tr, ORCID: 0000-0001-7470-5407

${ }^{* *}$ Dr. Öğretim Üyesi, Bandırma Onyedi Eylül Üniversitesi, İ.İ.B.F, Uluslararası İlişkiler Bölümü, mozekin@bandirma.edu.tr, ORCID: 0000-0001-8775-0936
} 
ISSN: $2148-6166$

Year: 23 Volume: 23 Issue: 2 December 2021 p.178-199 Article Type: Research Received Date: 17.05.2021 Accepted Date: 23.08.2021

\title{
The Relationship between Law and Politics within the Scope of State of Emergency: The US War on Terror and Guantanamo and Abu Ghraib as Spatial Representations of the State of Exception
}

\author{
Zeynep Arıöz, Muhammed Kürşad Özekin
}

\begin{abstract}
The relationship between law and politics continues to be controversial with regard to the effects of politics on law that disrupt justice and impartiality. The concept of the state of emergency is a buffer zone where this debate becomes clear. In the study, it is aimed to discuss the relationship between the law and the sovereign and the conflict between the political and the legal by referring to the state of emergency theories of thinkers such as Carl Schmitt, Walter Benjamin, and Giorgio Agamben. In this context, the study will focus on the relationship between the US war on terrorism after $9 / 11$ and its unilateral foreign policy and the state of emergency. After the attacks, US Foreign Policy has gone through a new period dominated by proactive and offensive security strategies. The US has undertaken military interventions in Afganistan and Iraq without an explicit authorization of the UN Security Council and a number of executions that suspended the international law on the detention and trial processes of the captured terrorists have been put into practice through new laws and the Executive Orders. In the study, Guantanamo and Abu Ghraib will be discussed within the context of the unilateral foreign policy of the United States and evaluated as spatial representations of the state of exception in which the law is instrumentalized in favor of the sovereign's decisions.
\end{abstract}

Keywords: US Foreign Policy, September 11 Attacks, the Global War on Terrorism, the State of Emergency, Guantanamo, Abu Ghraib. 


\section{Giriş}

Egemen ile hukuk arasındaki temel ilişki, öncelikli olarak egemenin yasa koyan ve yasayı koruyan olması zemininde kurulmaktadır. Bu yönüyle egemen, hukuku belirleyen, önceleyen ve olağanüstü hal durumlarına karar verendir (Schmitt, 2010a, s. 13). Böylece, egemen, her türlü normatif kıstasın ve hukukun dışında, politik birliğe karar veren özne olarak öne çıkmaktadır. Schmitt’e göre (2010a, s. 27-28) bütün hukuki mefhumlar içerisinde en çok güncel ve politik çıarların hükmü altında olan kavram egemenliktir. Bu açıdan Schmitt, Hans Kelsen'in pür normatif bilimler düzeyine yükseltmeye çalıştığı saf hukuk kuramını ve bu hukukta bir atıflar sistemi olarak temel norma gönderme yapan devlet anlayışını eleştirmektedir. Kelsen'in hukuki pozitivizm ve saf hukuk kuramına yönelttiği eleştiri, Schmitt’in kararcılık (decisionism) teorisinin genel bir taslağını formüle etmesi için başlangıç noktasını teşkil etmiştir. Hukukun üstünlüğü ve bağımsızlı̆̆ı karşısında siyasal olanın özerkliğini ve önceliğini vurgulayan Schmitt, desizyonist hukuk bilimi anlayışını ortaya koymaktadır. Bir politik teori olarak Schmitt'in formüle ettiği kararcılık, somut koşullarda kişisel karar alma yoluyla hukuktan haklı bir sapma olarak tanımlanabilir (Hoelzl, 2016).

Desizyonist hukuk bilimi anlayışı açısından, tüm normlar, kanunlar esasında egemenin verdiği kararlardır. Yasayı yapan hakikat değil, bizzat otoritenin kendisidir ve bu noktada egemenin iradesi esastır. Böylece karar, hukuk düzeninin kendisini yaratan varoluşsal bir kavram olarak zuhur etmektedir. Kararcılık/ Dezisionismus, hukukun başlangıcında siyasal olanı yani egemen erkin kararını görür. Bir üst otorite olarak devlet, farklı toplumsal sınıflar arasındaki çatışmalara egemen bir karar mercii olarak son vererek, politik bütünlüğü temin etmesi gereken iradedir. Bu noktada karar, normun kendisinden farklılaşır ve otorite, hukuku yaratmak adına haklı olmak gerekmediğini ispat eder. Dolayısıyla daha keskin bir ifadeyle yasa, emirdir ve otorite doğaldır. Otoritenin zıddı olan hakikat ve genel bir doğruluğa sahip olan norm, somut emrin tersine soyut bir şey olarak kalır (Schmitt, 2010b, s. 66-71). Devlet, dengenin bozulduğu, yani olağanüstü durumlarda, normal/normatif olanı tekrar tesis etmek için siyasal ${ }^{1}$ olanı elinde tutmaktadır. Schmitt, (2010a, s. 17) normatif olanla siyasal olan arasındaki gerilimi, siyaseti hukuktan dışlayarak değil, devlete bu siyasal niteliği kazandırarak aşmayı önerir. Dolayısıyla politik bir birlik olarak devlet, kendi içindeki ayrımları aşabilecek karar gücüne sahip bir varlıktır.

Schmitt (2010a) tüm düzenler gibi hukuki düzenin kaynağını da norma değil karara dayandırmaktadır. Nitekim bu karar, somut halini anayasa olarak bulmak-

\footnotetext{
1 Schmitt, siyasal olanın varlığını, dost düşman ayrımına dayandırır. Politik varoluş, bir düşmanın varlığına karar vermiş dostlardan oluşmaktadır. Schmitt'e göre düşman, yalnızca sahici bir olasılık olarak insanlardan oluşan yekpare bir vücut karşısında mücadelede bulunan benzer bir bütündür. Kamusal düşmana sahip olduklarında halklar, politik bir birlik, devlet olabilmişlerdir. Bu çerçevede siyasal kavramı, devletten önce gelmektedir (Schmitt, 2006, s. 54).
} 
tadır. Bu bağlamda anayasa hem yasal hem de politiktir. Böylesi bir karar gücüne sahip olan ise devlettir. Hukuku siyasete bağlayan bu görüş, dolayısıyla hukuku adil ve tarafsız kılma adına siyasetten koparan normatif görüşü tersine çevirir. Hukuku siyasetin dışında değil, siyasetle birlikte düşünür. Daha açık bir ifade ile hukuku koyan ve koruyan egemen erkin üstün konumundan dolayı hukuk ile siyaset arasında zorunlu ve doğal bir ilişki olduğunu vurgular. Bu anlayış, devleti bir hukuk düzeni ve aynı zamanda devletin iradesini de hukuk olarak değerlendirerek, hukukun kaynağını göstermiş olur. Bu deşifre, hukuku, siyasal olanla bir arada düşünmenin önünü açmanın yanı sıra siyaseti hukuku kuran ve onu önceleyen bir olgu olarak kabul eder (Bezci, 2006, s. 185).

Hukukun siyasetle kurduğu bu ilk teması deşifre etmek, sadece ulusal düzlemde değil küresel siyasette de hukuk ve siyasetin karmaşık ilişkisini anlamak adına önemli bir müdahaledir. Nitekim 11 Eylül saldırıları sonrası sözde "teröre karşı savaş” bağlamında Amerika Birleşik Devletleri’nin izlediği tek taraflı ve ofansif dış politika yönelimi ve güvenlik stratejileri adeta uluslararası hukukun ve en temel insan hakları normlarının askıya alındığı Schmittan bir "istisna halini” anımsatmaktadır. Bu noktadan hareketle ilgili çalışma Carl Schmitt, Walter Benjamin ve Giorgio Agamben gibi düşünürlerin olağanüstü hal kuramlarına atıfta bulunarak, hukuk ile egemen arasındaki ilişkiyi ve siyasal olanla yasal olan arasındaki çatışmayı uluslararası düzlemde tartışmayı amaçlamaktadır. Bu amaç doğrultusunda çalışma öncelikle olağanüstü hal ve istisna kavramalarını yukarıda isimleri zikredilen düşünürlerin görüşlerine atıfla hukuk ve siyaset arasındaki ilişki açısından tartışacaktır. Bu tartışmadan hareketle çalışma bir sonraki bölümde meseleyi uluslararası düzleme taşıyarak ABD’nin 11 Eylül saldırılarının ardından teröre karşı açtığı savaş ve izlediği tek taraflı dış politika ile olağanüstü hal arasındaki ilişkiyi irdeleyecektir.

11 Eylül saldırılarının ardından ABD, tek taraflı ve saldırgan güvenlik stratejilerinin hâkim olduğu bir dış politika anlayışı benimsemiş ve adeta küresel ölçekli bir olağanüstü hal durumu ilan etmiştir (Bush G. W., 2001). Terörle mücadele adına kongre tarafından geniş yetkiler ile donatılan ABD başkanı uluslararası hukukun temel normları kabul edilen kuvvet kullanma yasağı, meşru savunma, iç işlerine karışmama ve egemen eşitlik gibi ilkeleri hiçe sayarak önce Afganistan’da ve ardından Irak’ta geniş ölçekli askeri operasyonlar ve işgal süreci yürütmüştür. Birleşmiş Milletler Genel Sekreteri, BBC’ye yaptığı açıklamada, Irak'ın ABD öncülüğünde işgalinin BM Şartı'na aykırı, illegal bir eylem olduğunu ifade etmiştir (Annan, 2004). Ele geçirilen terör suçlularının tutukluluk durumları ve yargılanma süreçleri konusunda uluslararası savaş hukukunu askıya alan bir dizi uygulama, yeni yasalar ve Başkanlık Emirleri (Executive Orders) aracılığıyla hayata geçirilmiştir. ABD’nin uluslararası hukuktan doğan yükümlülüklerini askıya aldığı ya da dışına çıktığı örnekler olarak Guantanamo ve Ebu Gureyb cezaevlerindeki uygulamalar, hukukun, egemenin kararları lehine araçsallaştırıldığı, istisna halinin önemli mekânsal temsilleri olarak değerlendirilebilir. Terörle mücadele 
adına olağanüstü yetkiler kullanan Bush idaresi altında süresiz alıkoymaların ve kişileri uluslararası hukukun dışına çıkaran yasaların önemli birer temsili olan Guantanamo ve Ebu Gureyb Cezaevleri, Obama döneminde de faaliyetlerine devam etmiştir. Trump, Guantanamo Körfezi’ndeki gözaltı tesislerini açı tutma talimatı verdiği başkanlık kararnamesini imzalamış ve teröristlerin sıradan suçlular değil düşman savaşçılar olduklarını tekrar ederek teröre karşı küresel savaş bahanesi ile adeta istisna halinin olağanlaştığını ve sürekli hale geldiğini göstermiştir (https://www.theguardian.com/international, 2018).

\section{Hukuk ve Siyaset İlişkisi Bağlamında Olağanüstü Hal ve İstisna}

Egemenin hukukla ilişkisinin bir yönü, yasa koyması ve yasayı koruması yoluyla kurulurken ikinci yönü, bu yasaya istisna halini tespit etmesi ve hukuku askıya almasıyla ortaya çıkar. İstisna hali, egemenin olağanüstü koşulların varlığına karar vererek, hukuku askıya almasına sebep olan durumdur. Bu noktada Schmitt (2010a, s. 15) egemeni, olağanüstü hal ve istisna durumuna karar veren mercii olarak tanımlamıştır. Olağanüstü hal, mevzu hukukta öngörülmeyen ve olağanüstü önlemlerin uygulanmasını mecbur kılan her türlü politik, sosyal ve ekonomik karışıklığı ihtiva eder. Egemen, acil ve zorunlu bir durumun olup olmadığını tespit eden ve bu durumun bertaraf edilmesi için ne tür önlemler alınması gerektiğine karar verendir. Schmitt (2009, s. 34-36), hukuku siyasete karşı işlevsiz bırakan bu tutumun kaynağını egemene bağlar ve yeni durum, bir iktidarın teşhisine imkân verdiği an, hukuk için zemin oluşturmaktadır. Bu durumda iktidarın verdiği karar, hukuki normun geçerliliği karşısında tartışmasız üstünlüğünü kanıtlar. Yürütme organının, yargı organının gücünü üstlenmesi, egemenliğin bölünmez olduğu bir çağı, kuvvetler ayrımının siyasi modernliğin ön koşulu olmadığı bir çağı hatırlatmaktadır (Butler, 2005). Bu sürekliliğe Schmitt de dikkat çekmektedir. Ona göre çağdaş devlet kuramının tüm önemli mefhumları esasında dünyevileştirilmiş ilahiyat kavramlarıdır. Bir anlamda her şeye kadir Tanrı, her şeye kadir, omnipotenz, kanun koyucu haline dönüşmüştür. Böylece olağanüstü hal kavramının hukuk düzeni açısından barındırdığı anlam, mucizenin ilahiyat için taşıdığı anlama benzemektedir: Kanunlarının, bir istisna tarafından ihlali (Schmitt, 2010a, s. 41-43). Bu bağlamda olağanüstü hal, çağdaş bir egemenlik biçimini var eden bir edim olarak değerlendirilebilir. Hukukun askıya alınması hem var oluş hem de sonuçları bakımından egemenliği yeniden üretmektedir.

Hukuki düzen kavramının iki unsuru norm ve karar, olağanüstü hal durumunda karşı karşıya gelmektedir. Schmitt (2010a, s. 19-20), hukukla gerçek dünyanın birebir örtüşmediği durumlarda, hangi durumun istisna durumu olabileceğine karar verecek kişi belirlendiğinde, bu kişiye aynı zamanda, olağanüstü hal durumunda ne tür önlemler alınabileceğine karar verme yetkisinin de verilmiş olduğunu ifade eder. Böylece egemen, hukuku askıya alırken, yasanın kendisine bu yetkiyi ver- 
mesi açısından, hukuk düzeninin içinde kalır. Temel iddia olağanüstü halin hukuk dışı olmadığı, norm gibi kararın da hukuk çerçevesinde varlığını sürdürdüğüdür. Kaos ve anarşiden farklı bir durum olarak olağanüstü hal, esasen mevcut hukuk düzeni olarak değerlendirilmese de hukuki anlamda mevcut düzenin devamı ve bir parçasıdır. Böylece Schmitt, yasaların askıya alınmasının, yasal alandan türediğini göstermeyi hedeflemiş ve olağanüstü hali, hukuki bir bağlama yerleştirmeye çalışmışıı. Yasaların askıya alınması ile egemen yasanın dışında kalmaktadır ama yine de ona aittir. Çünkü istisna hali, var olan normal düzene atıfla tespit edilmektedir: "Normal olan, hiçbir şeyi kanıtlamaz, istisna her şeyi kanıtlar: yalnızca kuralı kanıtlamakla kalmaz, kural sadece istisna sayesinde yaşar. Olağanüstü hal normu askıya alarak, hukuki olan biçimsel bir öğeyi, kararı, tam bir saflıkla açığa vurur" (Schmitt, 2010a, s. 22).

Hukuk ile siyaset arasındaki bu ara bölgeyi inceleyen Agamben (2010, s. 168-169) olağanüstü halin yapısını "dışında olmak ama ait olmak” şeklinde ifade etmiş ve normun geçerliliğini koruduğunu ama gücü olmadığından uygulanamadığını ve yasa değeri taşımayan eylemlerin/tasarıların yasa gücü kazandığı bir hukuk rejimi olarak tanımlamıştır. İstisna halini açıklarken Agamben (2008), hukuk sistemlerinde farklı biçimlerde ortaya çıksa da istisna halinin günümüz dünyasında giderek olağanlaştığını vurgulamıştır. İstisna halini özellikle direniş hukuku sorunuyla ilintilendiren Agamben meseleyi İtalya, Almanya ve Fransa gibi farklı ülkelerdeki uygulamalar üzerinden ele almıştır. Birinci Dünya Savaşı'ndan günümüze istisna hali anayasalarla veya anayasalarda yer almaksızın siyasi erke tanınan yetkiler, bu yetkilerin görünümleri olan başkanlık kararları ve kanun hükmünde kararnameler ile hukuk düzenin bir parçası haline getirilmiştir. Her ne kadar İtalya'da istisna hali açıç̧a anayasada bulunmasa da 'acil durum kararnameleri', yani kanun hükmünde kararnameler aracılığıyla hayat bulmuş ve İtalyan anayasasının 77. maddesinde düzenlenerek zaman içinde hukukun olağan üretim kaynağı halini almıştır (Angiulli, 2009). Almanya'da ise Weimar Anayasasının 48. maddesi kamu düzeninin bozulması ya da tehdit edilmesi durumunda Başkana bazı temel haklar kısmen ya da bütünüyle askıya alma ve gerekirse silahlı kuvvetlerin desteğiyle gerekli müdahaleleri yapma yetkisi tanımıştır (Schmitt, 2011). Öyle ki 1925 ’te Schmitt, “dünya üzerindeki hiçbir anayasanın, Weimar Anayasası'nın yaptığı gibi, bir darbeyi bu kadar kolay yasallaştırmadığını” yazmıştır (Amarasinghe, 2020, s. 35). Benzer bir durumda Fransa'da görülmektedir. De Gaulle'ün isteği doğrultusunda Fransız anayasasının 16. maddesine eklenen bir hüküm ile kamu güçlerinin düzenli işleyişinin bozulması veya cumhuriyetin kurumları, milletin bağımsızlığı ve ülkenin bütünlüğünün tehdit edilmesi durumunda Cumhurbaşkanın gerekli önlemleri alabileceği öngörülmüştür (Constitution du 4 octobre 1958).

Güçlü demokratik gelenekleriyle öne çıkan İngiltere ve ABD'de de durum farklı olmamıştır. Birleşik Krallık’ta martial law (sıkı yönetim) vasıtasıyla İngiliz hukukuna giren istisna hali, Acil Durum Yasası ile Majestelerine olağanüstü hal 
ilan etme ve gerekli yasal düzenlemeleri çıkarma yetkisi tanımıştır. Burada askeri yasa, hukukun esasına değil, daha ziyade olağan hukukun üstünlüğü askıya alındığı dar, istisnai yetkilere işaret etmektedir (Capua, 1977). ABD’de ise olağanüstü hal ve istisna haline ilişkin anayasada açık ve detaylı düzenlemeler yer almasa da anayasanın sekiz ve dokuzuncu bölümleri Birlik'in yasaları yürürlüğe koymak, isyanları bastırmak ve saldırıları püskürtmek adına milis kuvvetleri göreve çağırabileceği ve isyan ve istila durumunda kamu güvenliği gereğince Habeas Corpus'un² askıya alınabileceği belirtilmiştir.

Tüm bu örneklerde görüleceği üzere hukukun askıya alınmasının neden olduğu “yasasızlık” hali esasında hukuk düzenin kendisinden bağımsız değildir. İstisna halini belirleyen tüm bu düzenlemeler bizatihi hukuk düzenin içinde üretilmiştir. Nitekim bu duruma vurgu yapan Agamben (2010, s. 167), olağanüstü halin özgül niteliğini Roma Hukuku'na kadar götürmektedir. Roma'da Senato, Cumhuriyeti tehlikeye düşüren ya da tehdit eden bir durum ile karşılaştı̆̆ında, devletin güvenliğini temin etmek için konsüllerin her türlü önlemi almaya zorlandığı bir senatus consultum ultimum, senatonun nihai yargısını açıklardı. Bu yönüyle Roma İmparatorluğu'nda olağanüstü hal, yasaların olmadığı bir alandır ancak gerçek anlamıyla bir diktatörlük değildir. Roma hukukundaki bu duruma atıfta bulunan Schmitt (2006b) de benzer bir şekilde "komiseryal (atanmış) diktatörlüğü̈" önceden var olan düzeni işler kılmak adına süresi, amacı ve kaynağıyla sınırlandırılmış karar verme gücü olarak görür. Ancak, sınırları belirlenmemiş olağanüstü hal durumu sürekli bir hal alabilir ve kamu düzenini koruma ideali kisvesiyle sınırlandırllamaz ve denetlenemez bir siyasal güce evirilebilir. Nitekim Roma senatosunun son bir kez diktatör olarak atadığı Ceaser kendini ömür boyu diktatör ilan etmiştir. Yine benzer bir şekilde Weimar Anayasası'nın mümkün kıldığı istisna hali, Hitler Almanya’sında istisna olmaktan çıkıp olağan bir hale dönüşmüştür. En yalın ifadeyle, bu oluşan yeni düzen yürürlükteki anayasaların varlığını sürdürmesine izin vermiş ancak anayasanın yanında istisna halinin olağanlaştığı ikinci bir yapı hukuk sisteminin içine yerleştirilmiştir (Reynolds, 2017, s. 39-40).

Günümüzde, olağanüstü hal, sadece baskıcı ve otoriter rejimlerin değil, demokratik ve ilerici yönetimlerin de bir ürünü halini almıştır. Nitekim 2015 yılında Fransa'da gündeme gelen terör olayları sebebiyle birçok kez uzatılmak üzere olağanüstü hal ilan edilmiş ve bu süre zarfı içinde siyasal erkin keyfi uygulamaları söz konusu olmuştur. Öyle ki BM İnsan hakları uzmanları, Fransa'yı terörizmle mücadele ederken temel özgürlükleri korumaya çağırmıştır (OHCHR, 2016). Bu

\footnotetext{
2 Kökenleri İngiliz örf ve âdet hukukuna dayanan Habeas Corpus, tutuklu bir kișinin, kanunen cezaevinde kalmaya zorlanabilmesi için önce mahkemeye çıkması ve bir mahkeme tarafından yargılanması gerektiğini belirten yasal emir anlamına gelmektedir. Habeas Corpus "ilgilileri, ellerindeki tutukluyu mahkemeye çıkarmaya çağıran adli bir emirdir. İlgililer, ellerindeki tutuklunun neden kısıtlandığını mahkemede anlatmak zorundadırlar. Eğer anlattıkları tatmin edici olmazsa, hâkim, tutuklunun serbest bırakılmasını emredebilir" (A.B.D. Dışişleri Bakanlığı Uluslararası Bilgi Programları Bürosu, 2004).
} 
noktada, her ne kadar egemen yasaların ortaya koyduğu hukuki sınırlar içinde hareket etmek zorunda olsa da olağanüstü hal ve istisna, hukuku siyaset karşısında ikinci plana atmaktadır. Lakin siyasal olarak egemen, nihayetinde hukukun askıya alınmasına ve gerekli önlem ve tedbirlerin uygulanmasına karar verendir. Bu yönüyle olağanüstü hal ve istisna sadece siyaset ve hukuk arasındaki ilişkiyi yansıtmakla kalmamış ayrıca şiddet ve güç kullanımı ile de yakın ilişki içinde olmuştur. Güç ve şiddet kullanma tekelini elinde bulunduran egemen, mevcut hukuk düzeni ile sınırlandırılmış ve kontrol altına alınmıştır. Ancak, şiddet kullanma tekelini elinde bulunduran siyasal erk, olağan durumda kullanamadığı şiddet unsurlarını istisnai koşullar altında kullanabilmektedir. Bu durumda şiddet, Benjamin'in (1996, s. 243-252) de ifade ettiği üzere ya mevcut ve kurulu hukuk düzenini korur ve ikmal eder ya da kendi ilkelerini yasa olarak dayatarak yeni kurucu erkin ve iktidar biçimlerinin ortaya çıkmasına hizmet eder. Dolayısıyla bir araç olarak şiddet olağanüstü hal şartlarında ya hukuk kurucu ya da hukuk koruyucu bir rol üstlenmektedir.

\section{İstisna Hali ve ABD Dış Politikası}

Hukuk, siyaset ve şiddet kullanımı bağlamında olağanüstü hal ve istisna durumuna ilişkin yukarıda yapmış olduğumuz tüm bu tespitler her ne kadar ulusal düzlemle ve bilhassa kamu hukuku alanıyla sınırlı görünse de uluslararası politikaya yönelik önemli sonuçları da bünyesinde barındırmaktadır. Günümüzde özellikle teröre karşı küresel savaş olarak adlandırılabilecek gelişmelerin sürekliliği karşısında olağanüstü halin daimi ve olağan hale geldiğini ve kalıcı olmaya azmetmiş bir istisna hukukunun kapsam, zaman ve mekân açısından belirsizlikler yarattığını söyleyebiliriz. Başta ABD olmak üzere demokratik devletlerin kendilerini ve vatandaşlarını korumak adına hukuk dışı uygulamalara başvurduğu günümüzde olağanüstü hal ve istisna kavramı, politikada gittikçe yaygınlaşan bir şekilde egemen hükümet paradigması olma temayülündedir (Schmitt, 2004; Benjamin, 1996). Geçici olma niyeti olmayan bu durum artık adeta hukukun üstünlüğü ve liberal uluslararası düzenin geleceği noktasında temel bir sorun halini almıştır. $\mathrm{Bu}$ durum bilhassa ABD’nin teröre karşı savaşı ve Guantanamo ve Ebu Gureyb cezaevlerindeki hukuk dışı uygulamalar özelinde endişe verici boyutlara ulaşmıştır.

Olağanüstü halin temeline, zorunluluk kavramı yerleşiktir. Burada zorunluluk, yasal olmayanı yasal kılmaktan çok, bir ihlalin haklı gösterilmesi işlevini görür. Bu bağlamda Amerika Birleşik Devletleri dış politikasının önemli unsurlarından birisi olan istisnacılık, ABD'nin zorunlu ve -yasal olmasa da- haklı liderliğine işaret etmekte ve ABD’nin dış politika davranışını anlamak açısından önem taşımaktadır. Başlangıçta Pasifik'e kadar ulaşıp kıta boyunca hâkimiyet sağlama amacı taşıyan daha sonra özellikle 20. Yüzyılın başından itibaren cihanşümul bir mahiyet kazanan Manifest Destiny, Amerikan halkına ve kurumlarına has değer- 
leri ile ABD’nin dünyayı dönüştürmek için özel, ayrıcalıklı, zorunlu bir misyona sahip olduğunu varsaymaktadır. Söz konusu düşünceye göre Birleşik Devletler, benzersiz nitelikleri nedeniyle, milletler arasında özel bir kadere sahiptir. Manifest Destiny, aslında on yedinci ve on sekizinci yüzyıl Amerikan istisnacılığının (American exceptionalism) on dokuzuncu yüzyıl versiyonu olarak karşımıza çımaktadır. Buna göre Amerika Birleşik Devletleri Eski Dünya'dan farklıdır; dünya tarihinde özel bir role sahiptir; Birleşik Devletler, tarihin yasalarına direnerek büyük güç statüsünü hiçbir zaman kaybetmeyecektir (Restad, 2015, s. 3-4). Bu özel kadere işaret eden Amerikan istisnacılı̆̆ ABD'yi, diğer uluslardan üstün ve dünyayı dönüştürmek için eşsiz bir misyona sahip addetmektedir (Paik, 2016 , s. 27; Malone ve Khong, 2003, s. 14).

Amerikan istisnacılığı, ABD deneyiminin diğer ülkelerdeki siyasal tecrübe ve yönetim sistemlerden farklı olarak, kendine özgü bir tarihsel süreç içerisinde ilerlediğine vurgu yapar ve bu yönüyle Birleşik Devletler tecrübesinin üstün olduğu ön kabulüne dayanır. Bu ön kabul özünde etik ve ahlaki değerler açısından Yeni Dünya'nın yaşlı Avrupa'dan farklı olduğu, insanlara daha iyi yaşam koşulları sunduğu ve dini ve siyasal özgürlüklerin gerçek anlamıyla Yeni Dünya'da neşet bulduğu düşüncesini yansıtır. Nitekim ABD, mezhep çatışmaları, yüzyıl savaşları, kıtlık, dinsel ve siyasal baskı gibi sorunlarla boğuşan Avrupalıların Eski Dünya'dan göç ederek oluşturdukları 'yeni' bir dünya olmuştur. Eski Dünya'ya karşı bağımsızlıklarını kazanan koloniler, politik erkin yetki alanının sınırlandırıldığı, güçler ayrılığı prensibinin kurumsallaştığı, bireysel hak ve özgürlüklerin anayasal güvence altına alındığı bir siyasal kültür ve nizam tesis etmişlerdir. Dolayısıyla ilk kuruluş yıllarından günümüze Amerikan siyasal kültürünün temel yapı taşlarını oluşturan serbest teşebbüs, siyasal liberalizm ve insani gelişme gibi değerler Amerikalılar tarafından evrensel olarak görülmekte ve tüm dünyaya benimsetilmesi gerektiği düşünülmektedir. Amerikan Bağımsızlık Bildirgesi’nin ve kurucu siyasal felsefesinin evrensel niteliği Birleşik Devletler'in özgün karakterine olan inancı kuvvetlendirmiş ve Amerikan dış politikasını da farklı kılarak ona "evrensel” ve "uygarlaştırıcı" bir misyon yüklemiştir.

Dış politikada Amerikan çıkarlarının meşrulaştırılması noktasında işlev gören bu "evrensel” ve "uygarlaştırıcı" dış politika yönelimi ABD tarihinin her dönemine farklı görünümlerde etki eden açık/kaçınılmaz bir yazgı olarak kabul görmüştür. Nitekim bu fikir ilk olarak Atlantik’ten Pasifiğe; Kuzey Kutbu'ndan tropiklere kadar olan bölgede yani ABD'nin bugün bulunduğu kıtada doğal bir yayılma hakkına sahip olduğu ve bu hakkın Tanrı tarafından bahşedildiği görüşüyle kendini göstermiştir. Amerika Birleşik Devletleri, Atlantik kıyısı ile Mississippi Nehri arasındaki orijinal sınırlarını müzakere, savaş ya da satın alma yoluyla genişleterek, batıda Pasifik Okyanusu ve güneyde Rio Grande Nehrine kadar uzanan bir kıta ülkesi haline gelmiş ve nihayetinde bu genişleme Manifest Destiny'e atfedilmiştir (Carlisle ve J. Geoffrey Golson, 2007, s. xvii). Amerikan misyonunun Tanrı tarafından bahşedildiği düşüncesi ve Amerikalıların seçilmiş halk olduğu duygusu za- 
man içerisinde Amerika kıtasını aşarak dünyanın geri kalanının özgürleştirilmesi ve uygarlaştırılması düşüncesine evirilmiştir. Bu bağlamda, Başkan Woodrow Wilson'un ABD’nin Birinci Dünya Savaşı'na dâhil olma gerekçesini açıklarken dış politikada özgürlük, eşitlik, gelişme ve demokrasi gibi değerlere atıfla Amerikan misyonunun diğer ülkelerden farklılık gösterdiğini vurgulaması önemlidir. Yine benzer bir şekilde savaş sonrası dünyasının şekillenmesinde Wilson'un başkanlığında ABD’nin liberal demokratik değerleri öncelemesi ve uluslararası düzlemde Milletler Cemiyeti gibi bir kurumsal yapılanmaya ön ayak olması Amerika'nın evrensel misyonunun tezahürü olarak kabul edilebilir (Divine, 1967, s. 6-10).

ABD'nin evrensel ve uygarlaştıııcı misyonunun somut anlamda ifade bulması daha çok İkinci. Dünya Savaşı sonrasında ortaya çıkmıştır. ABD’nin dünyaya liderlik etme anlayışıyla liberal uluslararası düzenin ve kurumlarının kurucusu ve hamisi olarak aktif rol oynaması ve dünya genelinde "rrzaya dayalı" hegemonya kurmak istemesi Amerikan istisnacılığının ve tarihsel misyonunun yakın dönem izdüşümleridir. Soğuk Savaş boyunca kendisini adeta liberal dünyanın lideri ve savunucusu olarak konumlandıran ABD özgürlük, demokrasi, serbest piyasa ekonomisi ve insani gelişme gibi değerleri dünya üzerinde yayma ve her türlü “despotluğa” karşı savunma görevini üstlenmiştir (Crothers, 2011, s. 25). Bu doğrultuda ABD, sadece rızaya dayalı olarak Avrupa'nın yeniden inşasında rol oynamamış Güney Kore, Filipinler, Vietnam, Küba, Nikaragua, Dominik Cumhuriyeti, Panama'da gerçekleştirdiği askeri müdahaleler ile uluslararası hukukun ve BM güvenlik sisteminin temelini teşkil eden egemen eşitlik, içişlerine karışmama ve kuvvet kullanma yasağı gibi esaslara da aykırı hareket etmiştir. ${ }^{3}$

Dolayısıyla hem yüksek-düzey politika yapıcılar hem geniş halk kesimleri tarafından benimsenen Amerikan istisnacılığı ve seçilmişlik duygusu sadece ABD'nin evrensel ve uygarlaştırıcı bir dış politik misyon benimsemesine neden olmakla kalmamış aynı zamanda müdahaleci dış politik yönelimine de zemin oluşturmuştur. Amerikan istisnacılığı, örnek (Exemplary) ve misyoner (Missionary) olma nitelikleri ile tek taraflı bir dış politika, tek taraflı bir enternasyonalizm geleneğine katkıda bulunmuştur (Restad, 2015, s. 10). Nitekim savaş sonrası oluşan uluslararası sistemde adeta kendini egemen siyasal erk olarak konumlandıran ve BM güvenlik siteminin ve yeni uluslararası düzenin kurucu güçlerinden biri olan ABD gerekli gördüğü noktada demokrasi, barış ve güvenlik bahanesiyle uluslararası hukuk ve iç hukuktan doğan yükümlülüklerini esnetmiştir. Her kadar ABD Anayasası, güçler ayrılığı ilkesi temelinde yapılandırılmış ve savaş ilan etme yetkisi anayasanın Birinci Maddesi 8. Bölümü’ne göre, Kongre’ye verilmiş olsa da askeri müdahale ve savaş ilanı konusunda başkana bazı esneklikler tanınmıştır.

\footnotetext{
3 Bu bağlamda ABD’nin uygarlaştırıcı ve özgürleştirici dış politika misyonunun neden olduğu uluslararası hukuk ihlallerinden birisi de Uluslararası Adalet Divanı tarafından "Nikaragua'da ve Nikaragua’ya Karşı Askeri ve Paramiliter Faaliyetler” kararı ile de tespit edilmiştir. (https:// www.icj-cij.org/public/files/case-related/70/6505.pdf, 1986).
} 
Amerikan Anayasa'nın İkinci Maddesi silahlı kuvvetlerin başkumandanı olma sorumluluğunu Başkan'a vermektedir. Savaş ilan etme yetkisi konusundaki bu kompleks sistemi düzenlemek üzere Kongre askeri gücün kullanımı hususunda başkanın elini güçlendirecek birtakım yetkilendirmeler yapmıştır. Bu noktada Kongre savaş durumunun varlığının tespiti, savaş ilanı ve olağanüstü halin ilanı başta olmak üzere Başkan veya yürütme organına yetki veren birçok tüzük çlkarmıştır (Elsea ve Weed, 2015). Kongre, 1973 yılında Kongre’yi 48 saat içinde bilgilendirmek ve kararın gerekçelerini Kongre üyelerine açıklamak şartıyla Amerikan Başkanlarının yabancı bir ülkeye asker göndermesini sağlayacak Savaş Yetkisi Yasası'nı çıkarmıştır. Bu yasa ile ABD başkanlarının Kongre'nin onayını almaksızın askeri operasyon kararlarında Kongre ile işbirliği içinde olması amaçlanmıştır. Bu çerçevede, 1975'ten 2019'a kadar, ABD başkanları, kongreye 168 rapor göndermiştir. Bu sayı başkanların Kongre'nin onayını almaksızın gerçekleştirebildikleri askeri operasyonların sayısını göstermesi bakımından dikkat çekmektedir (Congressional Research Service, 2019).

\section{ABD’nin Teröre Karşı Savaşı ve İstisna Halinin Mekânsal Temsilleri Olarak Guantanamo ve Ebu Gureyb}

Soğuk Savaş’ın ardından, Körfez Krizi’ne verdiği keskin karşılık ile kendisini Yeni Dünya düzeninin yegâne gücü olarak konumlandıran ABD, her ne kadar 1990-1991 Körfez Savaşı'nda ya da Balkanlar'da yaşanan askeri müdahalelerde çok taraflı bir yaklaşım benimsemiş gibi görünse de 1980'lerin sonundan günümüze $\mathrm{ABD}$ dış politikasında etkili olan tek taraflı ve ofansif eğilim giderek güçlenmiştir. ABD'nin tartışmasız gücü, $A B D$ istisnacılığının tarihsel mirası ve Amerika Birleşik Devletleri’nin iç siyasi yapısı bu eğilimi güçlendiren unsurlar olmuştur. ABD'nin agresif, tek taraflı dış politika anlayışına, temel hak ve hürriyetleri ve uluslararası hukuku ihlal etmekten ve askıya almaktan kaçınmayan idare biçimi eşlik etmiş ve 11 Eylül olaylarının ardından bu eğilim giderek ağırlık kazanmıştır (Malone ve Khong, 2003, s. 4). Yönetimde bulunan Neo-conlar, 11 Eylül saldırılarının iç kamuoyu ve uluslararası toplum üzerinde yarattı̆̆ı şok etkisini adeta araçsallaştırarak dış politikada uluslararası hukukun ve temel hak ve hürriyetlerin göz ardı edildiği köklü değişikliklere kapı aralamışlardır. Saddam Hüseyin idaresindeki Irak, Birleşik Devletler'in güvenliğine yönelik doğrudan ve fiili bir tehditte bulunmasa da Bush yönetimi "önleyici meşru müdafaa/önleyici savaş” doktrini çerçevesince Irak’ta hukuk dışı bir işgal süreci başlatmıştır. Rusya, Çin Halk Cumhuriyeti ve Fransa'nın, 1441 sayılı Güvenlik Konseyi Kararı’nın otomatik olarak Irak’a karşı güç kullanımına izin vermediğini ve zor kullanılması durumunda yeni bir Konsey kararına ihtiyaç duyulduğunu bildiren ortak açıklamasına (UNSC, 2002) rağmen ABD işgal politikasından vazgeçmemiştir. Bir milyondan fazla Iraklı sivilin ölmesi ve milyonlarca Iraklının mülteci konumuna 
düşmesiyle sonuçlanan ve uluslararası ölçekte etkisi halen daha devam eden Irak işgali, zaman içinde adeta olağanlaşan ve süreklilik kazanan bir uluslararası hukuk ihlali haline dönüşmüştür. Nitekim Irak'ta kitle imha silahlarının bulunduğuna yönelik tüm iddiaların Uluslararası Atom Enerji Ajansı tarafından geçersiz kılınmasına (IAEA, 2003) ve Saddam Hüseyin yönetiminin 11 Eylül saldırıları ve el-Kaide ile bağlantısı somut olarak ispatlanamamış olmasına rağmen ABD önce Afganistan sonra Irak özelinde olmak üzere teröre karşı küresel savaş ilan etmiştir. Terör tehdidi karşısında ABD’nin ve dünyanın güvenliğini korumak ve olası tehlikeleri önceden bertaraf etmek bahanesiyle BM Anlaşması'nın 2/4 Maddesi'nde yer alan kuvvet kullanma yasağına aykırı olarak önleyici meşru müdafaa hakkının (pre-emptive self defense) kullanıldığı iddia edilmiştir. Bu çerçevede ABD’nin Afganistan ve Irak müdahaleleri, istisna alanı içinde "barbarlığa” karşı "medeniyet” şeklinde meşrulaştırılmaya çalışılan savaşlar olmuşlardır (Reynolds, 2017, s. 202). Bilhassa 11 Eylül saldırılarının yarattığı güvensizlik ortamını fırsat bilen Bush yönetimi, adeta küresel ölçekli olağanüstü hal ilan ederek uluslararası hukuktan ve insani hukuktan doğan yükümlülüklerini askıya almıştır.

Bu çerçevede ABD’nin tek taraflı ve müdahaleci dış politika geleneğine dayanan Bush idaresi, teröre karşı zaman ve mekân açısından sınırları belli olmayan küresel ölçekli bir savaş ilan etmiş ve ABD anayasasında açıkça ifade edilmeyen Başkan'ın acil durum müdahale gücünün önünü açmıştır. Bush yönetimi, kamuoyuna açıklanmayan bir dizi yasal muhtıra ile acil durum başkanlık yetkisini gerekçelendirmiştir. Bu muhtıralar, terör şüphelilerinin tutuklanması ve yargılanması, bu kişilere karşı kullanılmasına izin verilen sorgulama yöntemleri ve yetkisiz gözetim gibi çeşitli konularda Başkan’a özel yetkiler sağlamıştır (Edelson, 2013, s. 129-130). 11 Eylül saldırısının ardından Bush idaresinin "teröre karşı savaş” bağlamında ilk askeri müdahalesi Afganistan'a gerçekleştirilmiştir. Başkan, “Teröre karşı savaşımız el-Kaide ile başlıyor ama burada bitmiyor. Küresel erişime sahip her terörist grup bulunana, durdurulana ve mağlup edilene kadar sona ermeyecektir” sözleriyle süresiz savaş ilan ederek adeta küresel bir misyon üstlenmiştir (Bush G. W., 2001). Bush, El Kaide'nin uluslararası bir terörist grup olarak değerlendirildiğini ve Cenevre Sözleşmesi'ne taraf olarak kabul edilemeyeceğini, bu nedenle, el-Kaide üyelerinin, Cenevre Sözleşmesi kapsamında değerlendirilemeyeceğini bildirmiştir (U. S. Department of State, 2002). Terör tehdidi karşısında Amerikan istisnacılığının evrensel ve özgürleştirici iddiası ve küresel misyonu aynı yıl ABD Ulusal Güvenlik Stratejisinde benzer bir biçimde şu şekilde ifade edilmiştir:

\footnotetext{
“Amerika Birleşik Devletleri, dünyada eşi benzeri görülmemiş bir güce ve nüfuza sahiptir. Özgürlük ilkelerine ve özgür bir toplumun değerine olan inançla sürdürülen bu pozisyon, benzersiz sorumluluklar, yükümlülükler ve fırsatlarla birlikte gelir. Bu milletin büyük gücü, özgürlüğü destekleyen güç dengesini geliştirmek için kullanılmalıdır” (Bush G. W., 2002, s. 1).
} 
11 Eylül saldırılarının ardından terörle mücadele etmek adına başkana terör saldırılarının faillerine ve onlara koruma sağlayanlara karşı silahlı kuvvetlerin kullanılması yetkisini veren "Askeri Güç Kullanma Yetkisi Yasası" yürürlüğe girmiştir. Askeri Güç Kullanma Yetkisi (AUMF), Başkan’a orduyu, tehdit olarak gördügü herhangi bir devlet, grup veya kişiye karşı kullanma imkânı tanımıştır. Yasa, belirli bölgelerde savaş açmayı yasal hale getirirken, örgütlere ve kişilere yönelik operasyonlara izin vermesiyle dikkat çekmiştir (Public Law 10740, 2001). ABD Başkanı, bir ay sonra 13 Kasım 2001 tarihinde yeni bir askeri emir yayınlamıştır. Terörle savaşta vatandaş olmayan kişilerin gözaltına alınması, muamelesi ve yargılanması ile ilgili bu emir, terörist eylemlere karıştığından kuşkulanılan, ABD yurttaşı olmayan kişilerin süresiz alıkoyulmasına ve askeri komisyonlarca yargılanmalarına yetki vermektedir (Military Order of November 13, 2001). Bu bağlamda, Afganistan'ın ABD tarafından işgal edilmesinden sonra, Küba'da Guantanamo Körfezi'nde Amerikan donanmasına ait askeri üste kurulan cezaevi, ABD'nin teröre karşı savaş bahanesiyle uluslararası hukuktan ve hukukun evrensel prensiplerinden doğan sorumluluklarını askıya aldığı çarpıcı bir örnek olmuştur. Nitekim Başkan Bush’un vermiş olduğu emir ile burada sözüm ona yargılanan ve tutuklu bulunan bireylerin hukuki statüsü ortadan kaldırılmıştır. Afganistan'ın işgali sonrası yakalanan Taliban savaşçıları, Cenevre Konvansiyonları'nda tanımlanan savaş tutsakları statüsünün dışında bırakıldıkları gibi, aynı zamanda Birleşik Devletler'in mevcut yasaları kapsamında da yargılamaya tabi tutulmamaktadır. Dolayısıyla haklarında bu karara varılan kişiler ne mahkûm, ne sanık olabilmişler, Agamben'in (2008, s. 10) de ifade ettiği gibi bütünüyle alıkoymanın nesneleri haline dönüşmüşlerdir. 11 Eylül terör saldırılarından bir ay sonra 25 Ekim 2001'de kabul edilen Amerikan Yurtseverlik Yasası, olası terör saldırılarının önüne geçmek için, güvenlik kuvvetlerinin yetki alanını genişleten temel hak ve özgürlüklerin anayasal güvencesini askıya alma olanağı taşıyan diğer bir adım olarak karşımıza çıkmaktadır (Department of Justice, 2001). Dahası ABD, Uluslararası Ceza Mahkemesi (UCM) kuruluş belgesi olan Roma Statüsü’ne taraf olmamakla birlikte taraf olan yabancı ülkelerde konuşlanan ABD askerlerini korumak için her türlü önlemi alabileceğine dair hükümler içeren Amerikan Askeri Personelini Koruma Yasasını (ASPA) kabul etmiştir. Bu yasa ile ABD, UCM'ye taraf ülkeleri ikili dokunulmazlık anlaşması imzalamaya zorlamakta, aksi halde ABD askeri yardımlarını kesmekle tehdit etmekte ve bu yolla ABD askerlerini savaş hukukunun dışına çıkarmaya çalışmaktadır (107th Congress, 2001).

ABD, Guantanamo Körfezi’nde alıkonan tutsakların yargılanacağı askeri mahkemeler için yeni kurallar belirlemiş ve Guantanamo'daki kimi tutsaklar için, Cenevre Sözleşmesi'nin şart koştuğu yasal hakları askıya aldıklarını, mahkemeye çıkartılmayacaklarını ve süresiz olarak alıkonacaklarını bildirmiş̧tir (Department of Defense, 2001). ABD hükümeti, süresiz alıkoyma ve hukukun askıya alınması ile temel yargı sınırlarını yeniden belirleyerek kendisine hukuk dışında bir ege- 
menlik alanı yaratmıştır. Guantanamo Körfezi’nde süresiz olarak alıkonan bu tutsaklar uluslararası hukukun tanıdığı yasal süreçlere tabi tutulamaz ve uluslararası hukuk tarafından korunamaz duruma getirilmişlerdir. Mevcut hukuk düzeni, güvenlik ve olağanüstü hal gerekçesiyle hem ulusal hem de uluslararası düzeyde askıya alınmıştır ve hukukun askıya alınması, devlet egemenliğinin yeniden inşasına zemin oluşturmuştur (Butler, 2005, s. 64-67). ABD yönetimi, terörizmle savaş gerekçesiyle olağanüstü hali süresiz bir şekilde uzatmakta ve Gunatanamo, kişilerin tutsak olarak değil, gözaltına alınmış kimseler olarak belirsiz, süresiz bir statü içine koyuldukları yeni bir yönetim biçimi olmayı sürdürmektedir. Alıkoyulanlar hiçbir yasal hakka sahip olmadıkları gibi ABD mahkemelerinin bu yargılamalara müdahale etme yetkisi de teknik anlamda ortadan kaldırılmıştır. Savunma Bakanlığı mahkûmların isimlerini bile 4 yıl sonra açıklamıştır (The New York Times, 2006). Bu kişiler adeta Agamben'in (1998, s. 136-143) işaret ettiği gibi egemen iktidar tarafından kuşatılan, nesneleştiren, yaşamları ve ölümleri askıya alınan "çıplak hayatlar" haline gelmişlerdir.

Bush yönetimi "düşman savaş̧̧”" gibi yeni bir kavramı icat ederken, hükümlüler veya savaş esirleri gibi mevcut uluslararası hukuk kategorilerinin dışında, tamamen yeni bir kişi kategorisi yaratmıştır. 11 Eylül'den bu yana çıkarılan yasalar aracılığıyla "düşman savaşçı” temel hak ve hürriyetlerden yoksun bırakılmıştır. Böylece evrensel hukukun ve ABD anayasasının kökeninde yer alan habeas corpus, bir mahkûmun tutukluluğunun hukuka uygunluğunu haklı göstermeye zorlayan emir, ihlal edilmiştir (Paik, 2016 , s. 156-160). Bush yönetimi 2006'da Askeri Komisyon Yasası'nı çıkararak kişileri süresiz hapis cezasına karşı koruyan habeas corpus ilkesinin ihlalini yasal olarak mümkün kılmış, aynı zamanda düşman savaşçıları belirleme ve mahkûmiyet koşulları ile ilgili olarak kendi hukukunu ortaya koyma noktasında Başkan'a mutlak yetki vermiştir. Böylece “yasadışı düşman savaşçılarını” yargılayan askeri komisyonların anayasaya aykırı tüm eylem ve uygulamaları teknik olarak yasallaştırılmıştır (Military Commissions Act Of 2006). Başkan Bush, aynı yıl ABD’nin ulusal güvenlik stratejisinde, ülkesinin bir savaşta olduğunu deklare ederek bir anlamda Birleşik Devletler yönetiminin benimsemiş olduğu bu hukuk dışı uygulamaları, evrensel ve özgürleştirici dış politika söylemi çerçevesince şu şekilde gerekçelendirmiştir:

\footnotetext{
“Amerika gelecekteki barışın temellerini atmak için benzeri görülmemiş bir fırsata sahiptir. Tarihimize ilham veren idealler- özgürlük, demokrasi ve insan onuru- dünyanın her yerindeki bireylere ve uluslara giderek daha fazla ilham veriyor... Bu ayrılmaz öncelikler -teröre karşı savaşmak, savaşı kazanmak ve zorbalığa ve umutsuzluğa alternatif olarak özgürlüğü teşvik etmek- şimdi 4 yıldan fazla bir süredir Amerikan politikasına rehberlik ediyor” (Bush G. W., 2006).
}

Obama yönetimi de benzer bir eğilimi devam ettirmiştir. Başkan Obama, Guantanamo’yu kapatma vaadini gerçekleştirmediği gibi Ulusal Savunma Yetki Ta- 
sarısı'nı imzalayarak cezaevinin kapatılmasını zorlaştıran hükümleri onaylamıştır (Public Law 114-92, 2015). Başkan Obama, Afganistan'da ABD liderliğindeki Teröre Karşı Küresel Savaş'ın sona erdiğini ancak artık ABD’yi yok etmeye kararlı belirli gruplara odaklanılacağını açıklamıştır (U.S. News, 2013). Bu bağlamda ABD’nin, Afganistan'daki varlığı devam etmiş, ardından gelen ABD Başkanı Donald Trump, Afganistan'daki Amerikan askeri varlığını genişletmiştir (Council of Foreign Relations , 2021). Bush, Obama ve Trump idaresi tarafından, teröre karşı savaş misyonu ve Askeri Güç Kullanma Yetkisi yabancı ülkelerdeki askeri operasyonlara yasal gerekçe olarak gösterilmeye devam etmiştir.

Guantanamo örneğine benzer bir şekilde 2002 yılında Kongre’den Irak işgalinin önünü açan yeni bir Askeri Güç Kullanma Yetkisi (Public Law 107-243, 2002) geçirilmiş ve 2003 Irak işgalini takiben Irak'ın Ebu Gureyb kasabasında yer alan eski bir cezaevi Amerika Birleşik Devletleri tarafından tutukevi haline getirilmiştir. Ebu Gureyb cezaevi, uluslararası hukukun dışında, egemenin bir istisna hali olarak tanımladığı ve yönettiği yeni bir egemenlik icrası örneği olmuştur. Ebu Gureyb, ABD’nin uluslararası hukuku askıya aldığı tek taraflı dış politikasının bir diğer önemli örneğini temsil etmiştir. Bu husus, münferit ya da izole bir olaydan ziyade Cenevre sözleşmelerini aşmaya yönelik hükümetin ve askeri liderliğin uyumlu ve kararlı bir girişimi olarak değerlendirilebilir (Hersh, 2004, s. xviii-xix). Ebu Gureyb’teki fiziksel işkence, cinayet, taciz, tecavüz ve sodomi görüntülerinin ifşa olmasının ardından ABD yönetimi hem kendi kamuoyunca hem de uluslararası toplum tarafından mahkûmlara karşı işkence, savaş suçu ve insanlığa karşı suçlar işlemekle suçlanmıştır. ABD Savunma Bakanı Donald H. Rumsfeld daha sonra ABD'li yetkililer tarafından da sıklıkla ifade edileceği gibi, Ebu Gureyb’teki suiistimalleri “istisna” olarak değerlendirmiştir. Her ne kadar George W. Bush ve onu takip eden yönetimler Ebu Gureyb’te yaşanan insanlık dışı olayların münferit olduğunu ve ABD'nin resmi politikası olarak kabul edilemeyeceğini ifade etse de Irak'ın genelinde, Afganistan'da ve Guantanamo'da düşman olarak tanımlanan kesimlere yönelik yapılmış olan işkenceler ve acımasız muameleler kurumsallaşmış bir uygulamaya işaret etmektedir. Nitekim Kızılhaç, Uluslararası Af Örgütü ve İnsan Hakları İzleme Örgütü'nün tüm bu yerlere ilişkin gerçekleştirdiği gözlem ve araştırmalar, Ebu Gureyb’te yaşananların münferit ve izole olaylar olmadığını doğrular mahiyettedir (Smeulers ve Niekerk, 2009).

Yayınlamış olduğu kapsamlı raporda İnsan Hakları İzleme Örgütü, Irak’taki sivillerin aleyhlerine hiçbir suçlama yapılmadığı halde aylarca gözaltında kaldıklarını ve Ebu Gureyb cezaevinin aslında yeni bir Guantanamo haline dönüştüğünü bilhassa ifade etmiştir. Raporda, yaşanan istismar örüntüsünün, ordu düzenine aykırı hareket eden askerlerin bireysel eylemlerinden kaynaklanmadığı, aksine Bush yönetiminin hukuku ve kuralları göz ardı eden yönetim anlayışının bir parçası olduğu ortaya konulmuştur (Human Rights Watch, 2004). Nitekim Ebu Gureyb'te yaşanan gayri insani ve gayri hukuki olayları soruşturmakla yetkilendirilen askeri komite bile cezaevindeki uygulamaların ve sorgulama yöntemlerinin 
hâlihazırda ABD’nin Guantanamo'daki askeri üssündeki tutukevinde denendiği ve elde edilen başarı doğrultusunda Ebu Gureyb cezaevinde uygulanmaya geçirildiği tespit edilmiştir. Öte yandan Irak’taki gözaltı merkezleri ve cezaevlerinden sorumlu ABD’li General Geoffrey Miller'in göreve getirilmeden önce Guantanamo Üssü'nde bulunan tutukevinin eski komutanı olması tesadüften uzak bir durumdur (Hersh, 2004, s. 32). Dolayısıyla Guantanamo'daki tutukluluk ve sorgulama uygulamalarına benzer şekilde Ebu Gureyb'de de meydana gelen işkence ve şiddet olaylarının münferit vakalar olmadığı açıktır ve esasında istisna olarak görülenin kural halini aldığını gösterir niteliktedir.

Guantanamo ve Ebu Gureyb özelinde ifşa olan tüm bu insanlık dışı olayları mümkün kılan ise terörün önlenmesi ve uluslararası güvenliğin temin edilmesi adına ABD’nin egemen siyasal erk olarak uluslararası hukuku göz ardı etmesi ve siyasal tercihleri noktasında küresel ölçekte olağanüstü hal koşullarını belirlemiş olmasıdır. Nihayetinde Schmittyen (2010a, s. 13) anlamda değerlendirildiğinde egemen siyasal erk olarak ABD, hukuku askıya alan ve gerekli önlem ve tedbirlerin uygulanmasına karar verendir. Dolayısıyla hem ABD'nin iç hukukunun hem de uluslararası hukukun sınırları dışında gri bölgeler olarak tesis edilen Guantanamo ve Ebu Gureyb cezaevleri temel hak ve hürriyetlerden kopuşun en belirgin olduğu istisna mekânları olarak ortaya çıkmaktadır. Bu çerçevede oluşan bu istisna mekânlarında hâkim olan güç ise hukuk ve evrensel normlardan ziyade bizzat egemenin kendi iradesidir. Nitekim Guantanamo Üssü'ndeki tutukevinin ve Irak'taki cezaevlerinin eski sorumlusu Orgeneral Geoffrey Miller (BBC, 2014) "Tutsakların bir köpekten daha önemli olduğunu düşünmesine izin verirseniz kontrolü kaybedersiniz" diyerek bu kişilerin yalnızca birer bedenden ibaret olduğu ve bu kişilere karşı yapılacak kötü muamelenin hukuka aykırı olmayacağı yönündeki zihinsel alt yapıyı açığa vurmuştur. Dolayısıyla hiçbir değeri olmayan bedenler olarak burada bulunan tutsaklar normal hukuksal düzenin dışına itilmiş ve egemen erkin siyasal iradesine teslim edilmiştir. Bu durum tutukluların maruz kaldığı fiziksel, psikolojik ve cinsel istismarın sürekliliğini temin etmekle beraber faillere de zımni olarak yargısal muafiyet sağlamıştır. Nitekim işkencelerle ilgili olarak yürütülen askeri kovuşturmalardan çıkan kararlarda görevi ihmalden suçlu bulunan birkaç askere verilen küçük cezalar dışında mahkûmların öldürülmelerinden ve uğradıkları tacizlerden hiçbir askeri veya sivil lider cezai olarak sorumlu tutulmamıştır (Nuckols, 2008).

Yine aynı şekilde ABD adına Irak’ta hizmet veren özel askeri şirketler de zımni bir yargısal bağışıklıktan yararlanmıştır. Söz konusu özel askeri şirketlerle ilgili olarak uluslararası hukukta genel kabul görmüş bir uygulama olmadığı gibi şirketler de kendilerini silahlı çatışma hukukuna bağlı kabul etmemektedirler. Bu şirketlerin personelleri için komuta ve kontrol noktasında açık bir görev tanımlaması olmadığı gibi konuşlandıkları devletlerin iç hukukundan da muaf tutulmaktadırlar (Percy, 2009, s. 58-59). Ebu Gureyb’te kötü muameleye maruz kalmış 71 mahkûma 5,28 Milyon dolar tazminat ödemek zorunda kalan Engility Holdings 
dışında hiçbir özel askeri şirket ciddi bir ceza ve mahkûmiyet almamıştır (CBS News, 2013). İşkencelerin emir komuta zincirine bağlı olduğunu kabul etmeyen Bush yönetimi yaşananları genel olarak "birkaç çürük elma” açıklamasıyla değersizleştirmiştir (CNN, 2004; Bejesky, 2013). Amerika Birleşik Devletleri Senatosu Silahlı Hizmetler Komitesi ABD nezaretindeki tutukluların gördüğü kötü muameleye yönelik yapılan kendi başlarına hareket eden "birkaç çürük elma" açıklamasını kabul edilemez bulmuştur (Committee on Armed Services U.S. Senate, 2008). Ebu Gureyb cezaevindeki sorgulamalardan sorumlu bulunan CACI firması ise ilk kez 23 Nisan'da 2019 tarihinde ABD federal yargısı önüne çıkmış ve "200 yıllık hükümranlık dokunulmazlı̆̆ı prensibini tehlikeye atmak" iddiası ile yargılamaya itiraz etmişsir. Dolayısıyla hukuki yaptırım mekanizmalarının tam anlamıyla işlemediği Guantanamo ve Ebu Gureyb gibi istisna mekânları, egemenlik ve hukuk arasındaki gerilimi temsil etmektedir (https://news.bloomberglaw. com, 2019). Bu bağlamda Amerika Birleşik Devletleri’nin artık etkin bir hukuk devleti ve dünya çapında insan hakları ve demokrasinin önde gelen şampiyonu olup olmadığı tartışmalıdır (Alford, 2017, s. 240).

\section{Sonuç}

Amerikan istisnacılığı Amerika'nın değerlerinin, siyasi sisteminin ve tarihinin benzersiz olduğunu ve ABD’nin üstün değerlerini tüm dünyaya yaymakla ilgili zorunlu kaderinin ABD’yi özel kıldığını varsaymaktadır. Bu bağlamda ABD’nin uluslararası siyasette ayırt edici rol oynama hakkına sahip olduğunu ifade eden istisnacılık, dış politika davranışını şekillendiren önemli unsurlardan birisidir. SSCB'nin dağılması, Körfez Krizi'ne verilen kesin karşılık ile H. W. Bush yeni bir dünya düzeninin doğuşunu ilan etmiş ve Soğuk Savaş sonrasında ABD diş politikası, iddia ettiği yeni dünya düzeninin $\mathrm{ABD}$ önderliğinde sürdürülmesi üzerine şekillenmiştir. 11 Eylül 2001 saldırılarının ardından "ya bizimlesiniz ya da bize karşı” ültimatomunu destekleyen tek taraflılık, dış politikada hâkim unsur olmuştur. ABD bu çerçevede Anti-Balistik Füze (ABM) anlaşmasından çekilmek, Kyoto Protokolü’nden ayrılmak, 1972 Biyolojik ve Toksin Silah Sözleşmesi'nin güçlendirilmesine engel olmak, Uluslararası Ceza Mahkemesi Statüsü’nü onaylamayı reddetmek gibi biz dizi adım atmışıı. Bush yönetimi 11 Eylül saldırılarının ardından "teröre karşı açtığı savaşta" olağanüstü hal ilan etmiş ve Cenevre Sözleşmesi'ni uygulamayacağını açıklamıştır. Terörle mücadele adına olağanüstü yetkiler kullanan Bush idaresi altında süresiz alıkoymaların ve kişileri uluslararası hukukun dışına çıkaran yasaların önemli birer temsili olan Guantanamo ve Ebu Gureyb Cezaevleri, Obama döneminde de faaliyetlerine devam etmiştir. Trump Yönetimi, Kasım Süleymani operasyonunu, 2001 tarihli Askeri Güç Kullanma Yetkisi ve Başkan'a bir saldıııdan hemen sonra hızla karşılık verme yetkisi tanıyan Savaş Güçleri Yasası ile meşrulaştırmıştır (Gypson, 2019). Bu bağlamda ola- 
ğanüstü hal, yeni bir egemenlik icrasını var eden bir edim olarak çağımızın genel bir hali olarak görünmektedir. Hukukun askıya alınması hem varoluş hem de sonuçları bakımından egemenliği yeniden üretmektedir. Schmitt, yaratılan yasasızlık bölgesinin mevcut hukuk düzeniyle bağlantılı olduğunu ve istisna durumuna karar verecek kişi belirlendiğinde, bu kişiye aynı zamanda, olağanüstü hal koşullarında ne tür önlemler alınabileceğine ilişkin karar verme yetkisinin de verilmiş olduğunu ifade eder. Böylece egemen, hukuku askıya alırken, yasanın kendisine bu yetkiyi vermesi açısından, hukuk düzeninin içinde kalmaktadır (Çelebi, 2010, s. 286). ABD Başkanlarının, yasanın kendilerine tanıdığı geniş yetkilerle teknik olarak hukuk düzeni içinde kalırken aynı zamanda uluslararası hukuku askıya alan tek taraflı politikaların yürütücüsü olmaları bu çerçevede anlam kazanır.

Şiddeti, her defasında hukuki bir bağlama yerleştirmeye çalışan Schmitt'e karşı Benjamin (2010, s. 36-37), devletin olağanüstü hal yoluyla, yasasızlığı kendisine katmasına karşı çıkar. Yasanın şiddet/zor ile olan bağlantısını ortaya koyan Benjamin için hukuk kurma ve hukuk düzenini oluşturma şiddetten bağımsız bir eylem değildir. Daha yalın bir ifade ile şiddete bağlı bir amaç, iktidar adı altında zorunlu olarak kendini hukuk biçiminde ortaya koyar. Bu bağlamda Benjamin, çağdaş hukukun esasını, en haklı bulunduğu durumlar da dâhil olmak üzere, bireyin amacını hukuk dışında gerçekleştirebileceği tüm araçları almak ve bunu hukukun araçlarıyla ikame etmek olarak tespit eder. Her yeni şiddet edimi, yeni bir hukuk yaratacağı için, hukuk, bireylerin elindeki şiddeti, kendisine yönelik bir tehlike olarak görür. Böylece modern hukuk, doğal amaçlara yönelmiş her türlü şiddeti ele geçirmeyi hedefleyen bir eğilimi ortaya koymaktadır. Bu bağlamda şiddetin birinci işlevi, hukuk kurmak olurken, ikinci işlevi de hukukun korunması olarak karşımıza çıkmaktadır. Yasayı koruyan şiddet, ordu ya da polis tarafından temsil edilmektedir (Benjamin, 2010, s. 23-26; 1996, s. 240-242). Bu kavramsallaştırma, olağanüstü hal yasalarıyla kendisini meşrulaştıran rejimlere cevap verir ve faşist devletlerin aslında bir istisna haline dayandıklarını gösterir. Benjamin böylece içinde yaşadığımız çağı, olağanüstü halin istisna değil, kural olduğu bir çağ olarak deşifre eder. (2004, s. 41). ABD'nin izlediği tek taraflı dış politikalar hukukun, siyaset karşısındaki konumu giderek egemenin kararına teslim ettiği, Benjamin’in "istisna değil kural olarak tanımladığı” bu dönemi temsil etmektedir. Dışarıda uluslararası hukuku devre dışı bırakıp, içeride hukuku askıya alan iktidarlar, yine de hukuku uyguladıklarını öne sürerek, hukukun norm unsurunu yok sayıp, karar unsuruna dayanmaktadırlar. Hukuk, belirli bir siyasetin izlenmesi sürecinde, amaca giden araçların uygunluğunu düzenlemekten ibaret kalmaktadır. Askeri Güç Kullanma Yetkisi veya Savaş Yetkisi Yasası gibi sınırları net olmayan yasalar yoluyla iktidar, hukuku kendi kararı adına araçsallaştırmaktadır. Barış, düzen, güvenlik, adalet ve huzur gibi değerler etrafında beliren hukukun üstünlügü fikri, yine bu değerler adına askıya alınmaktadır. Yeni iktidar biçimi, zorunluluk halini, hukukun askıya alınmasına sebep olan geçici durumu, hukukun içinde kalıcı bir önlem haline dönüştürmüştür. Kanun hükmünde kararnameler, devlet 
başkanlarının verdiği emirler, süresiz alıkoymalar, savaş yetkisi yasaları uluslararası hukukun sistematik olarak askıya alındığı pratikler olarak olağanüstü halin sürekliliğini göstermektedir. Guantanamo ve Ebu Gureyb süresiz, keyfi gözaltılar ve işkencelerin sembolik mekânları olarak Amerika Birleşik Devletleri’nin küresel siyasette tek taraflı dış politikasının, istisna halinin kural olduğu yeni bir egemenlik biçiminin uluslararası hukuk bağlamındaki tezahürleridir.

\section{Kaynakça}

107th Congress. (2001, November 1). https://www.congress.gov/107/bills/s1610/BILLS107s1610is.pdf adresinden alındı

A.B.D. Dışişleri Bakanlığı Uluslararası Bilgi Programları Bürosu. (2004). Amerika Hakkında Amerika Birleşik Devletleri Anayasası. https://tr.usembassy.gov/wp-content/ uploads/sites/91/abd-anayasasi.pdf adresinden alındı

Agamben, G. (1998). Homo sacer_ sovereign power and bare life . California: Stanford University Press.

Agamben, G. (2008). Olağanüstü Hal. Varlık Yayınları.

Agamben, G. (2010). Olağanüstü Hal. A. Çelebi (Dü.) içinde, Şiddetin Eleştirisi Üzerine. Metis Yayınevi.

Alford, R. (2017). Permanent State Of Emergency Unchecked Executive Power and the Demise of the Rule of Law. Montreal \& Kingston: McGill-Queen's University Press.

Amarasinghe, P. (2020). Agamben's two missing factors; Understanding state of emergency through colonialism and racial doctrine. Open Political Science, 3, 34-46.

Angiulli, G. (2009). The State of Emergency in Italy. University of Trento.

Annan, K. (2004, September 16). Iraq war illegal, says Annan. http://news.bbc.co.uk/2/hi/ middle_east/3661134.stm adresinden alındı

BBC. (2014, June 15). Iraq abuse 'ordered from the top'. http://news.bbc.co.uk/2/hi/ americas/3806713.stm adresinden alındı

Bejesky, R. (2013). The Abu Ghraib Convictions: A Miscarriage of Justice. Buffalo Public Interest Law Journal, 32(4), 103-175.

Benjamin, W. (1996). Critique of Violence. M. Bullock, \& M. W. Jennings içinde, Walter Benjamin Selected Writings Volume 1 1913-1926 (s. 236-252). London: Harward University Press.

Benjamin, W. (2004). Pasajlar. İstanbul: YKY.

Benjamin, W. (2010). Şiddetin Eleştirisi Üzerine. İstanbul: Metis Yayınları.

Bezci, B. (2006). Carl Schmitt'in Politik Felsefesi. İstanbul: Paradigma Yayıncllı.

Bush, G. W. (2001, September 20). Address to a Joint Session of Congress and the American People. 02 21, 2021 tarihinde https://georgewbush-whitehouse.archives. gov/news/releases/2001/09/20010920-8.html adresinden alındı

Bush, G. W. (2001, September 14). Proclamation 7463 - Declaration of National Emergency by Reason of Certain Terrorist Attacks.

Bush, G. W. (2002). The National Security Strategy of the United States of America. Washington: The White House .

Bush, G. W. (2006). The National Security Strategy of The United States of America. Washington: The White House. 
Butler, J. (2005). Kırılgan Hayat. Metis Yayınevi.

Capua, J. V. (1977). The Early History of Martial Law in England from the Fourteenth Century to the Petition of Right. The Cambridge Law Journal, 36(1), 152-173.

Carlisle, R. P., \& J. Geoffrey Golson. (2007). Manifest Destiny and the Expansion of America. California: ABC-CLIO.

CBS News. (2013, January 8). U.S. contractor to pay $\$ 5.28$ million to Abu Ghraib prisoners. https://www.cbsnews.com/news/us-contractor-to-pay-528-million-to-abughraib-prisoners/ adresinden alındı

CNN. (2004, May 6). Bush vows abusers will face justice. https://edition.cnn.com/2004/ ALLPOLITICS/05/05/bush.abuse/index.html adresinden alındı

Committee on Armed Services U.S. Senate. (2008). Inquiry into the Treatment of Detainees in U.S. Custody Before the Senate 110th Congress. Committee Print. https://www. armed-services.senate.gov/imo/media/doc/Detainee-Report-Final_April-22-2009.pdf adresinden alındı

Congressional Research Service. (2019). The War Powers Resolution:Concepts and Practice. Congressional Research Service.

Constitution du 4 octobre 1958. (tarih yok). https://www.legifrance.gouv.fr/: https://www. legifrance.gouv.fr/loda/id/JORFTEXT000000571356/2019-07-01/ adresinden alındı

Council of Foreign Relations . (2021, 02 24). The U.S. War in Afghanistan 1999-2020. https://www.cfr.org/timeline/us-war-afghanistan adresinden alındı

Crothers, L. (2011). The cultural roots of isolationism and internationalism in American foreign policy. Journal of Transatlantic Studies, 9(1), 21-34.

Çelebi, A. (2010). Şiddete Karşı Siyaset Hakkı. Şiddetin Eleştirisi Üzerine. içinde Metis Yayınları.

Department of Defense. (2001, December 11). Senate Hearing 107-513. Department Of Defense's Implementation Of The Presıdent's Military Order On Detention Treatment And Trial By Milıtary Commıssıon Of Certain Noncitızens In The War On Terrorısm: https://www.govinfo.gov/content/pkg/CHRG-107shrg80293/html/CHRG107shrg80293.htm adresinden alındı

Department of Justice. (2001). The USA PATRIOT Act: Preserving Life and Liberty. 02 15, 2021 tarihinde https://www.justice.gov/archive/ll/what_is_the_patriot_act.pdf adresinden alındı

Divine, R. (1967). Second Chance: The Triumph of Internationalism in America During the Second World War (. New York: Atheneum.

Edelson, C. (2013). Emergency Presidential Power: From the Drafting of the Constitution to the War on Terror . University of Wisconsin Press.

Elsea, J. K., \& Weed, M. C. (2015). Declarations of War and Authorizations for the Use of Military Force: Historical Background and Legal Implications. C. Perez içinde, Enactment of War and the Use of Military Force: Background and Legal Implications (s. 1-108). Nova Science Publishers.

Gypson, K. (2019, June 24). Trump, Congress Spar Over Iran War Powers. 02 03, 2021 tarihinde www.voanews.com: https://www.voanews.com/usa/trump-congress-sparover-iran-war-powers adresinden alındı

Hersh, S. M. (2004). Chain of Command to Road From 9/11 to Abu Ghraib. Harper Collins. Hobbes, T. (2001). Leviathan. İstanbul: YKY.

Hoelzl, M. (2016). Ethics of decisionism: Carl Schmitt's theological blind spot. Journal for Cultural Research, 20(3), 235-246. 
http://www.protezionecivile.gov.it/. (tarih yok). http://www.protezionecivile.gov.it/en/ national-service/activities/emergency/state-of-emergency adresinden alındı

https://news.bloomberglaw.com. (2019, April 25). 02 03, 2021 tarihinde Bloomberg Law: https://news.bloomberglaw.com/federal-contracting/unprecedented-ruling-returnsabu-ghraib-case-to-fourth-circuit adresinden alındı

https://www.caci.com/. (tarih yok). 01 20, 2021 tarihinde alındı

https://www.france24.com/en/. (2017, 05 24). https://www.france24.com/en/20170524france-president-macron-seeks-extend-state-emergency-manchester adresinden alındı https://www.icj-cij.org/public/files/case-related/70/6505.pdf. (1986). https://www.icj-cij. org/public/files/case-related/70/6505.pdf adresinden alındı

https://www.theguardian.com/international. (2018, January 30). Donald Trump signs executive order to keep Guantánamo Bay open. https://www.theguardian.com/us-news/2018/jan/30/ guantanamo-bay-trump-signs-executive-order-to-keep-prison-open adresinden alındı

Human Rights Watch. (2004). The Road to Abu Ghraib. 04 20, 2021 tarihinde https:// www.hrw.org/reports/2004/usa0604/ adresinden alındı

IAEA. (2003, March 7). The Status of Nuclear Inspections in Iraq: An Update. International Atomic Energy Agency: https://www.iaea.org/newscenter/statements/status-nuclearinspections-iraq-update adresinden alındı

Malone, D. M., \& Khong, Y. F. (2003). Unilateralism and U.S. Foreign Policy: International Perspectives. Boulder: Lynne Rienner Publishers.

Malone, D. M., \& Khong, Y. F. (2003). Unilateralism and U.S. Foreign Policy: International Perspectives. Boulder: Lynne Reinner.

Military Commissions Act Of 2006. (tarih yok). 01 08, 2021 tarihinde https://www.loc. gov/rr/frd/Military_Law/pdf/PL-109-366.pdf adresinden alındı

Military Order of November 13, 2. (2001, November 16). Executive Orders. 02 21, 2021 tarihinde https://fas.org/irp/offdocs/eo/mo-111301.htm adresinden alındı

Nuckols, B. (2008, January 11). Associated Press. Military prosecution in Abu Ghraib scandal ends: http://archive.boston.com/news/nation/articles/2008/01/11/military_ prosecution_in_abu_ghraib_scandal_ends/ adresinden alındı

OHCHR. (2016, January 19). https://www.ohchr.org. UN rights experts urge France to protect fundamental freedoms while countering terrorism: https://www.ohchr.org/EN/ NewsEvents/Pages/DisplayNews.aspx?NewsID=16966\&LangID= adresinden alındı

Paik, A. N. ( 2016 ). Rightlessness : testimony and redress in U.S. prison camps since World War II /. The University of North Carolina Press.

Patrick, S., \& Forman, S. (2002). Multilateralism and U.S. Foreign Policy: Ambivalent Engagement. Boulder: Lynne Rienner.

Percy, S. (2009). Private Security Companies and Civil Wars. Civil Wars, 11(1), 57-74.

Public Law 107-243. (2002, Oct 16). Authorization For Use Of Military Force Against Iraq Resolution Of 2002. 01 23, 2021 tarihinde PLAW-107publ243.pdf (govinfo.gov): https:// www.congress.gov/107/plaws/publ243/PLAW-107publ243.pdf adresinden alındı

Public Law 107-40. (2001, September 18). https://www.congress.gov/107/plaws/publ40/ PLAW-107publ40.pdf adresinden alındı

Public Law 114-92. (2015, Nov 25). 01 23, 2021 tarihinde https:/www.congress.gov/114/ plaws/publ92/PLAW-114publ92.pdf adresinden alındı

Restad, H. E. (2015). American Exceptionalism: An Idea that Made a Nation and Remade the World. London: Routledge. 
Reynolds, J. (2017). Empire, Emergency And International Law. Cambridge : Cambridge University Press.

Schmitt, C. (2004). The Theory of the Partisan: A Commentary/Remark on the Concept of the Political. East Lansing: Michigan State University.

Schmitt, C. (2006). Siyasal Kavramı. Metis.

Schmitt, C. (2009). Tarih ve Siyaset Üzerine İki Deneme. Paradigma Yayıncılık.

Schmitt, C. (2010a). Siyasi İlahiyat, Egemenlik Kuramı Üzerine Dört Bölüm. Dost Kitabevi.

Schmitt, C. (2010b). Parlamenter Demokrasinin Krizi (2 b.). Dost Kitabevi.

Schmitt, C. (2011). The Dictatorship of the Reich President Acoordin to Art 48 of the Reich Constitution. Constellations, 18(3).

Schmitt, C. (2011). The Dictatorship of the Reich President Acoordin to Art 48 of the Reich Constitution. Constellations, 18(3), 299-323.

Smeulers, A., \& Niekerk, S. v. (2009). Abu Ghraib and the War on Terror-a case against Donald Rumsfeld? Crime, Law and Social Change , 51, 327-349.

The New York Times. (2006, March 4). U.S. Reveals Identities of Detainees. 01 08, 2021 tarihinde https://www.nytimes.com/2006/03/04/politics/us-reveals-identities-ofdetainees.html adresinden alındı

U. S. Department of State. (2002, February 7). 58. White House Press Secretary announcement of President Bush's determination re legal status of Taliban and Al Qaeda detainees. U.S. Department of State: https://2009-2017.state.gov/s/l/38727. htm adresinden alındı

U.S. News. (2013, May 23). https://www.usnews.com/news/articles/2013/05/23/obamaglobal-war-on-terror-is-over adresinden alındı

UNSC. (2002). S/2002/1236. Joint statement from the Popular Republic of China, the Federation of Russia, and France: https://undocs.org/en/S/2002/1236 adresinden alındı 